\title{
P04.83. What factors influence the use of integrative medicine (IM) modalities by infectious disease (ID) physicians?
}

\author{
K Shere-Wolfe ${ }^{*}$, J Tilburt ${ }^{2}$, C D'Adamo ${ }^{1}$, B Berman ${ }^{1}$, M Chesney $^{3}$ \\ From International Research Congress on Integrative Medicine and Health 2012 \\ Portland, Oregon, USA. 15-18 May 2012
}

\section{Purpose}

The purpose was to assess factors that may influence the use of IM modalities by ID physicians in their practice.

\section{Methods}

In a 2010 national survey of 1000 practicing ID physicians, participants were asked to report the extent (major, minor or not at all) to which the following considerations played a role in their recommendation/referral of IM modalities: (1) Knowledge of how and when to use them; (2) Amount of clinical research showing clear benefit; (3) Insurance; (4) Cost; (5) Reliable referral base; (6) Concern for professional reputation; (7) Fear of judgment from colleagues; (8) Insufficient regulatory oversight of supplements; and (9) Potential drug interactions with botanicals/supplements.

Table 1

\begin{tabular}{llll}
\hline Factor & $\begin{array}{l}\text { Number of } \\
\text { respondents }\end{array}$ & $\begin{array}{l}\text { Major } \\
\text { role (\%) }\end{array}$ & $\begin{array}{l}\text { Minor or Not } \\
\text { at all (\%) }\end{array}$ \\
\hline Drug Interactions & 293 & 82 & 18 \\
\hline Research & 294 & 80 & 20 \\
\hline Knowledge & 294 & 72 & 28 \\
\hline Insurance & 292 & 24 & 76 \\
\hline Cost & 293 & 39 & 61 \\
\hline Referral base & 288 & 39 & 61 \\
\hline Professionl reputation & 293 & 14 & 86 \\
\hline Fear of judgement & 293 & 4 & 96 \\
\hline Regulation oversight & 294 & 69 & 31 \\
\hline
\end{tabular}

\section{Results}

A total of 311 (31\%) ID physicians responded to the survey. The mean age was 49 and $64 \%$ of respondents were male. Their responses to the questions are listed below.

\section{Conclusion}

For ID physicians, factors that were considered a major influence on the use of IM modalities included: potential drug interactions, clinical research, knowledge of IM modalities, and regulatory oversight. Factors that played a minor/no role in the use of IM modalities included fear of judgment and concern for professional reputation.

\section{Author details}

'University of Maryland, Baltimore, USA. ${ }^{2}$ Mayo Clinic, Rochester, USA. ${ }^{3}$ University of California, San Franscisco, USA.

Published: 12 June 2012

doi:10.1186/1472-6882-12-S1-P353

Cite this article as: Shere-Wolfe et al: P04.83. What factors influence the use of integrative medicine (IM) modalities by infectious disease (ID) physicians? BMC Complementary and Alternative Medicine 2012 12(Suppl 1): P353.

'University of Maryland, Baltimore, USA

Full list of author information is available at the end of the article 